\title{
TWO STEP FORGING OF ALLOY 718
}

\author{
N.K. Park, J.T. Yum, Y.S. Na, I. S. Kim, D.H. Kim, S.J. Choe \\ Department of Materials Engineering \\ Korea Institute of Machinery \& Materials, Changwon, Rep. of Korea, 641-010
}

\begin{abstract}
A two step forging route was employed for Alloy 718 pancake forging. The effect of forging parameters on the evolution of microstructures within the pancakes during deformation was evaluated by metallographic observations. With the critical forging parameters of the dynamic recrystallization obtained by compression tests, FE simulation can effectively be utilized to predict detailed variations of the microstructures due to dynamic recrystallization for all forged pancakes. The distribution of forging parameters within a work piece is shown to be important in determining final grain sizes.
\end{abstract}

\section{Introduction}

One or two step forging processes are routinely employed for superalloy disk forging. Two step forging may be used especially for complex geometry forging of a superalloy disk with a uniform microstructure and properties. Depending on the forging temperature and post treatment, Alloy 718 can be grouped into three different types; i.e, standard, high strength and direct age versions[1]. Standard 718 is finish-forged well above the $\delta(\mathrm{Ni} 3 \mathrm{Cb})$ phase solvus temperature between $1038^{\circ} \mathrm{C}$ and $1066^{\circ} \mathrm{C}$ to make use of its reasonably good forgeability. The resulting grain size is $\Lambda$ STM 4-6. High Strength 718 is forged initially above the $\delta$ solvus temperature, but finished in the end slightly below the $\delta$ solvus temperature, resulting in a final grain size of ASTM 8 or finer. Direct-age 718 is finish-forged even at lower temperatures below the $\delta$ solvus temperature followed by the conventional direct aging treatment, resulting in a finer grain size less than ASTM 10 with various mechanical properties; such as tensile strength and LCF properties.

The selection of the different forging routes is determined by the design requirements of microstructures and mechanical properties. The change in microstructures is closely related with dynamic and static recrystallization during forging or post heat-treatment[2]. The recrystallization behavior is influenced by process variables such as the forging temperature, strain rate, initial grain size and amount of deformation[3]. The aim of this research is to investigate the effect of strain distribution on the final microstructure in the two step forging process. FEM simulation was carried out to predict the evolution of microstructures.

\section{$\underline{\text { Experimental Procedure }}$}

Material

The material used in this study was the premium quality Alloy 718 of high $\mathrm{Nb}$ content. The Superalloys 718, 625, 706 and Various Derivatives Edited by E.A. Loria

The Minerals, Metals \& Materials Sociefy, 1997 
chemical composition of the alloy is as shown in Table 1 . The average grain size of the center part of billet was ASTM 5-6 $(50 \mu \mathrm{m}-60 \mu \mathrm{m})$.

Table I . Chemical compositions of Alloy 718 (wt.\%)

\begin{tabular}{|c|c|c|c|c|c|c|c|}
\hline $\mathrm{C}$ & $\mathrm{S}$ & $\mathrm{Mn}$ & $\mathrm{Si}$ & $\mathrm{Cr}$ & $\mathrm{Mo}$ & $\mathrm{Co}$ & $\mathrm{Ti}$ \\
\hline 0.027 & 0.0005 & 0.06 & 0.05 & 18.03 & 2.87 & 0.34 & 0.96 \\
\hline $\mathrm{Al}$ & $\mathrm{B}$ & $\mathrm{Fe}$ & $\mathrm{Cu}$ & $\mathrm{Ni}$ & $\mathrm{F}$ & $\mathrm{Nb}+\mathrm{Ta}$ & others \\
\hline 0.47 & 0.04 & 17.81 & 0.05 & Bal. & 0.04 & 5.38 & - \\
\hline
\end{tabular}

\section{Compression test}

In order to obtain flow curves and to evaluate dynamic recrystallization behavior, compression tests were carried out using cylindrical specimens ( $8 \mathrm{~mm}$ diameter $\times 12 \mathrm{~mm}$ length) at the temperatures between $927^{\circ} \mathrm{C}$ and $1066^{\circ} \mathrm{C}$ and at the strain rates between $5 \times 10^{-4} \mathrm{~s}^{-1}$ and $5 \times 10^{0} \mathrm{~s}^{-1}$. Tests were carried out in vacuum $\left(\sim 10^{-2}\right.$ torr $)$ up to a true strain of 0.7 . Test specimens were induction-heated to the test temperatures at a heating rate of $5^{\circ} \mathrm{Cs}^{-1}$ and were held for $5 \mathrm{~min}$ at the same temperature to obtain a uniform temperature within the specimens. The specimens were quenched by purged $\mathrm{N}_{2}$ gas as soon as the compression tests were completed.

Two step forging

Pancake forging experiments were carried out by a 2500 -ton screw press using cylindrical billets $(140 \mathrm{~mm} \mathrm{D} \times 152 \mathrm{~mm} \mathrm{~L})$. In order to reduce die friction and get smooth deformation, a fine graphite lubricant was spread on $\mathrm{H}-13$ flat dies which was preheated to $300^{\circ} \mathrm{C}$. All the billets were held at $1040^{\circ} \mathrm{C}$ for 2 hours to start with a constant and homogeneous grain distribution. The resulting grain size was $\Lambda$ STM 3-4( $\sim 110 \mu \mathrm{m})$. The forging temperature for the billets was varied between $982^{\circ} \mathrm{C}$ and $1038^{\circ} \mathrm{C}$, and the upset ratio in the first and second forging was varied while the total strain was controlled to be around 0.65 . The transfer time of the work piece from the furnace to the press was less than 10s. Forging conditions are shown in Table II.

Table II. Screw press forging conditions

\begin{tabular}{|c|c|c|c|c|c|c|}
\hline \multirow[b]{2}{*}{ Specimen } & \multicolumn{3}{|c|}{$1^{\text {st }}$ Forging } & \multicolumn{3}{|c|}{$2^{\text {nd }}$ Forging } \\
\hline & $\begin{array}{c}\text { Ratio } \\
(\%)\end{array}$ & $\begin{array}{c}\text { Temp. } \\
\left({ }^{\circ} \mathrm{C}\right)\end{array}$ & Cooling & $\begin{array}{c}\text { Ratio } \\
(\%)\end{array}$ & $\begin{array}{c}\text { Temp. } \\
\left({ }^{\circ} \mathrm{C}\right)\end{array}$ & Cooling \\
\hline A & 52 & 1010 & FAC & 24 & 982 & FAC \\
\hline B & 44 & 1010 & " & 40 & 982 & " \\
\hline $\mathrm{C}$ & 25 & 1010 & " & 54 & 982 & $"$ \\
\hline $\mathrm{D}$ & 52 & 1038 & " & 24 & 1010 & " \\
\hline $\mathrm{E}$ & 44 & 1038 & " & 40 & 1010 & " \\
\hline $\mathrm{F}$ & 25 & 1038 & $"$ & 54 & 1010 & $"$ \\
\hline
\end{tabular}

A-C : $1^{\text {st }}$ High Strength, 2nd Direct Age $\quad$ D-F : $1^{\text {st }}$ Convention, $2^{\text {nd }}$ High Strength

FAC : Fan Air Cool

\section{FEM Simulation}

The non-isothermal rigid-plastic FE code, DEFORM-2, was used for the forging simulation to 
simulate the effect of process variables such as strain, strain rate and temperature on the grain size distribution of the forged pancakes. The first and second forging wcre simulated with ten steps increments in total, and the distributions of strain, strain rate and temperature for each step were calculated.

Based on the microstructure data obtained by compression tests, the conditions for the dynamic recrystallization were established. The static recrystallization, which may occur under slow cooling conditions, is neglected in this study. It is then reasonable to assume that the recrystallized grain size depends on the test temperature and strain rate as predicted by the Zencr-Holloman parameter[4].

To estimate the variation of grain size with deformation, the simulation results on local temperature, strain, and strain rates within the forged pancakes were used. The local temperature and strain at a certain simulation step were presented as a single data point in the strain vs. temperature graph, and compared with the experimental data on the dynamic recrystallization established by the compression tests for comparable strain rate conditions.

\section{Results and Discussion}

\section{Dynamic Recrystallization during Compression Tests}

Typical true stress - true strain curves for different combinations of strain rates and temperatures are shown in Figure 1. The shape of the flow curves depends on the strain rate and temperature. The flow curves show a single-peak when the strain rate is above $5 \times 10^{-2} \mathrm{~s}^{-1}$ or the temperature is below $982^{\circ} \mathrm{C}$. Whercas, the flow curves show multiple-peaks when the strain rate is below $5 \times 10^{-2} \mathrm{~s}^{-1}$ or the temperature is above $982^{\circ} \mathrm{C}$. In the single-peak flow curve, the initial work hardening rate decreases continuously with strain, and the flow curve reaches essentially a peak stress. Afterwards, the curve decreases to a steady state stress level. The softening of the curve can be attributed to dynamic recrystallization.

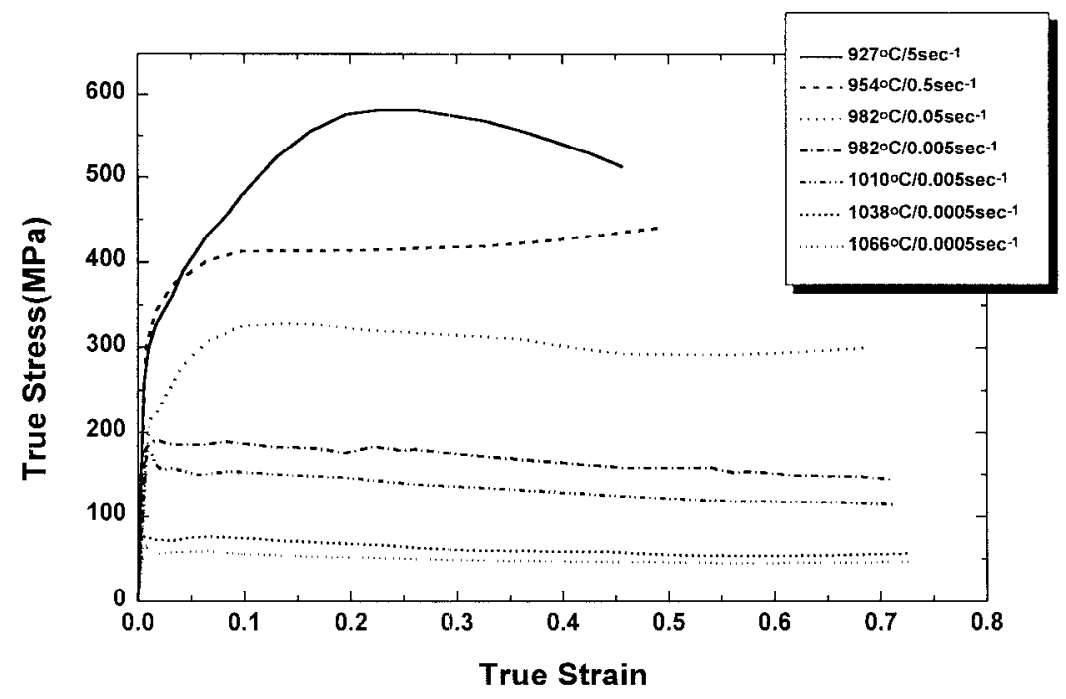

Fig. 1. Plot of compressive true stress vs, true strain of Alloy 718. 
Figure 2 shows typical $\theta(=\mathrm{d} \sigma / \mathrm{d} \varepsilon)$ vs. $\sigma$ plots derived from the flow curves at different strain rates and temperatures. The $\theta$ vs. $\sigma$ plots show that the $\theta$ value decreases rapidly with strain due to active dynamic recovery, and later it decreases slowly. At large strains, there is a second drop in the slope which can be attributed to the dynamic recrystallization, and the $\theta$ value becomes nil at the peak stress ( $\sigma_{\max }$ ) at which $\varepsilon=\varepsilon_{\mathrm{c}}$, and the work hardening rate and work softening rate is well balanced. The stress which corresponds to the dynamic recrystallization is referred to as the critical stress $\left(\sigma_{\mathrm{c}}\right)$ and the strain that corresponds to the critical stress $\left(\sigma_{\mathrm{c}}\right)$ is referred to as the critical strain $\left(\varepsilon_{\mathrm{c}}\right)$ for the dynamic recrystallization [5].

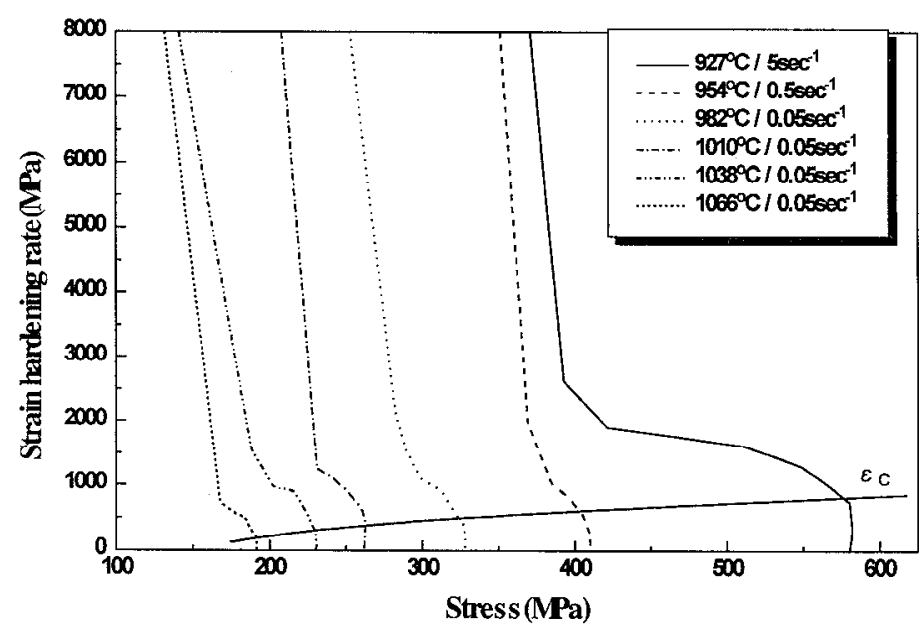

Fig. 2. Plot of strain hardening rate vs. flow stress for the given test conditions.

In general, the values, $\sigma_{\mathrm{c}}, \sigma_{\max }, \varepsilon_{\mathrm{c}}$ and $\varepsilon_{\max }$, increase systematically with a decreasing temperature and/or increasing strain rate. It was observed in the curves that the highest $\varepsilon_{\mathrm{c}}(\sim 0.19)$ and $\varepsilon_{\max }(\sim 0.24)$ were obtained at $927^{\circ} \mathrm{C}$ and $5 \mathrm{~s}^{-1}$, and the lowest $\varepsilon_{\mathrm{c}}(\sim 0.053)$ and $\varepsilon_{\max }$ $(\sim 0.064)$ were obtained at $1066^{\circ} \mathrm{C}$ and $0.0005 \mathrm{~s}^{-1}$.

\section{FEM simulation}

Flow patterns obtained by FE simulation are quite similar to those that are actually prepared from the forged pancakes as shown in Figure 3. The simulation results of the six pancakes forging conditions indicated low strains near the die contact area and high strains at the center part of the work piece. The strain distribution was varied from high strains at the hub section to low strains at the rim section. The simulated temperature distribution indicated that the surface temperature of the specimen was decreased due to the rapid heat loss to the dies, whilst the temperature at the center part of the specimen was increased during deformation due to deformation heating. The temperature rise from the initial forging temperature was varied from $20^{\circ} \mathrm{C}$ to $50^{\circ} \mathrm{C}$. Strain rates were shown to have the highest distribution at the top edge corner of the work piece.

Simulation results for cach forging conditions are summarized in Table III. In general, the strain contours for each forging conditions show that the strain distributions at the first step forging is larger than that at the second step forging. The large strain distribution of the tirst step forging is caused by the rapid temperature drop near the surface due to die chilling. For the given forging conditions, the 
maximum load was 2400 ton which was below the press capacity.

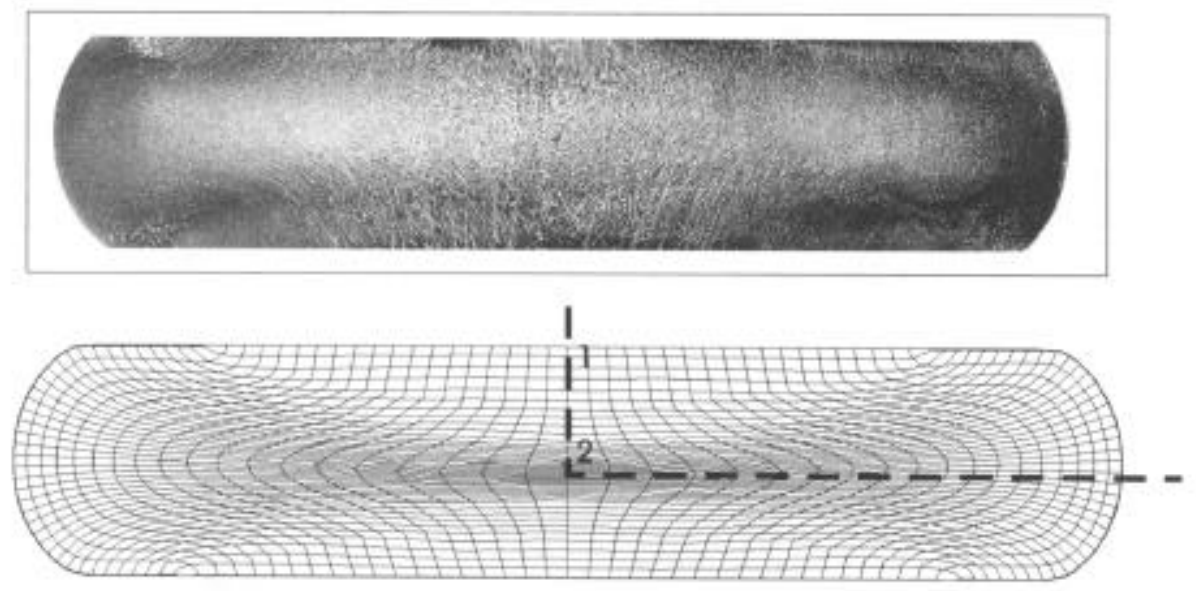

Fig. 3. Experimental and simulated material flow in a finish-forged pancake.

Table III. FEM simulation results under various forging conditions

\begin{tabular}{|c|c|c|c|c|c|c|c|c|}
\hline \multirow{3}{*}{ Specimen } & \multicolumn{4}{|c|}{$1^{\text {s }}$ Forging } & \multicolumn{4}{|c|}{$2^{\text {nd }}$ Forging } \\
\hline & \multicolumn{3}{|c|}{ Distributions } & \multirow{2}{*}{$\begin{array}{c}\text { Maximum } \\
\text { load } \\
\text { (ton) }\end{array}$} & \multicolumn{3}{|c|}{ Distributions } & \multirow{2}{*}{$\begin{array}{c}\text { Maximum } \\
\text { load } \\
\text { (ton) }\end{array}$} \\
\hline & Strain & $\begin{array}{c}\text { Strain rate } \\
\left(\sec ^{-1}\right)\end{array}$ & $\begin{array}{l}\text { Temp. } \\
\text { (C) }\end{array}$ & & Strain & $\begin{array}{c}\text { Strain rate } \\
\left(\sec ^{-1}\right)\end{array}$ & $\begin{array}{l}\text { Temp. } \\
\text { (C) }\end{array}$ & \\
\hline A & $\begin{array}{c}0.063- \\
2.015\end{array}$ & $\begin{array}{l}0.17- \\
7.136\end{array}$ & $\begin{array}{l}668 \text { - } \\
1074 \\
\end{array}$ & 928 & $\begin{array}{c}0.119= \\
0.63\end{array}$ & $\begin{array}{c}0.068= \\
0.767\end{array}$ & $\begin{array}{l}619- \\
1003\end{array}$ & 2400 \\
\hline B & $\begin{array}{l}0.04- \\
0.956\end{array}$ & $\begin{array}{c}0.0197= \\
1.684\end{array}$ & $\begin{array}{l}636- \\
1048 \\
\end{array}$ & 715 & $\begin{array}{c}0.2= \\
1.2 \\
\end{array}$ & $\begin{array}{c}0.11= \\
0.79 \\
\end{array}$ & $\begin{array}{l}640- \\
1027\end{array}$ & 2190 \\
\hline C & $\begin{array}{l}0.03- \\
0.607 \\
\end{array}$ & $\begin{array}{l}0.01- \\
0.514 \\
\end{array}$ & $\begin{array}{l}635- \\
1035 \\
\end{array}$ & 670 & $\begin{array}{c}0.13- \\
1.59\end{array}$ & $\begin{array}{c}0.02- \\
0.26 \\
\end{array}$ & $\begin{array}{l}634 . \\
1034\end{array}$ & 1672 \\
\hline D & $\begin{array}{l}0.05- \\
2.053\end{array}$ & $\begin{array}{l}0.06- \\
0.598\end{array}$ & $\begin{array}{l}660= \\
1096\end{array}$ & 916 & $\begin{array}{c}0.09- \\
0.68\end{array}$ & $\begin{array}{c}0.05= \\
0.59\end{array}$ & $\begin{array}{l}636- \\
1029 \\
\end{array}$ & 2005 \\
\hline E & $\begin{array}{c}0.03= \\
1.27\end{array}$ & $\begin{array}{c}0.026- \\
1.09\end{array}$ & $\begin{array}{l}670- \\
1082 \\
\end{array}$ & 674 & $\begin{array}{l}0.1- \\
0.85\end{array}$ & $\begin{array}{c}0.06- \\
0.72 \\
\end{array}$ & $\begin{array}{l}635- \\
1039 \\
\end{array}$ & 1679 \\
\hline F & $\begin{array}{c}0.014- \\
0.576 \\
\end{array}$ & $\begin{array}{c}0.009- \\
0.53 \\
\end{array}$ & $\begin{array}{l}689- \\
1059 \\
\end{array}$ & 486 & $\begin{array}{c}0.09= \\
1.36 \\
\end{array}$ & $\begin{array}{c}0.06- \\
0.88 \\
\end{array}$ & $\begin{array}{l}649= \\
1062 \\
\end{array}$ & 1621 \\
\hline
\end{tabular}

Microstructure Analysis by FEM Simulation

The grain size of forged pancakes depends very much on the forging condition as well as the location within the work piece. Figure 4 shows the microstructures of the center part (Location 2) under various forging conditions as noted in Figure 3. A, B and C samples are composed of fully recrystallized grains, while $\mathrm{D}, \mathrm{E}$ and $\mathrm{F}$ samples are composed of necklace microstructures. Figure 5 shows that the microstructure of surface region (Location 1) is not recrystallized during forging. 
Figure 6 shows the history of temperature and effective strains at certain steps during forging simulation and the demarcation line for the recrystallization as given by the function of temperature and strain $\left(\varepsilon_{\mathrm{c}}\right)$ at a fixed strain rate. The demarcation line was obtained by compression tests. The simulated stain rate was varied within the range of $0.01 \mathrm{~s}^{-1}$ to $7 \mathrm{~s}^{-1}$ for the given test conditions, so that all the recrystallization was evaluated at the initial strain rates $0.005 \mathrm{~s}^{-1}$ and $5 \mathrm{~s}^{-1}$. In Figure 6 , the first step forging is presented by the closed symbols, and the second step forging is given by open symbols.

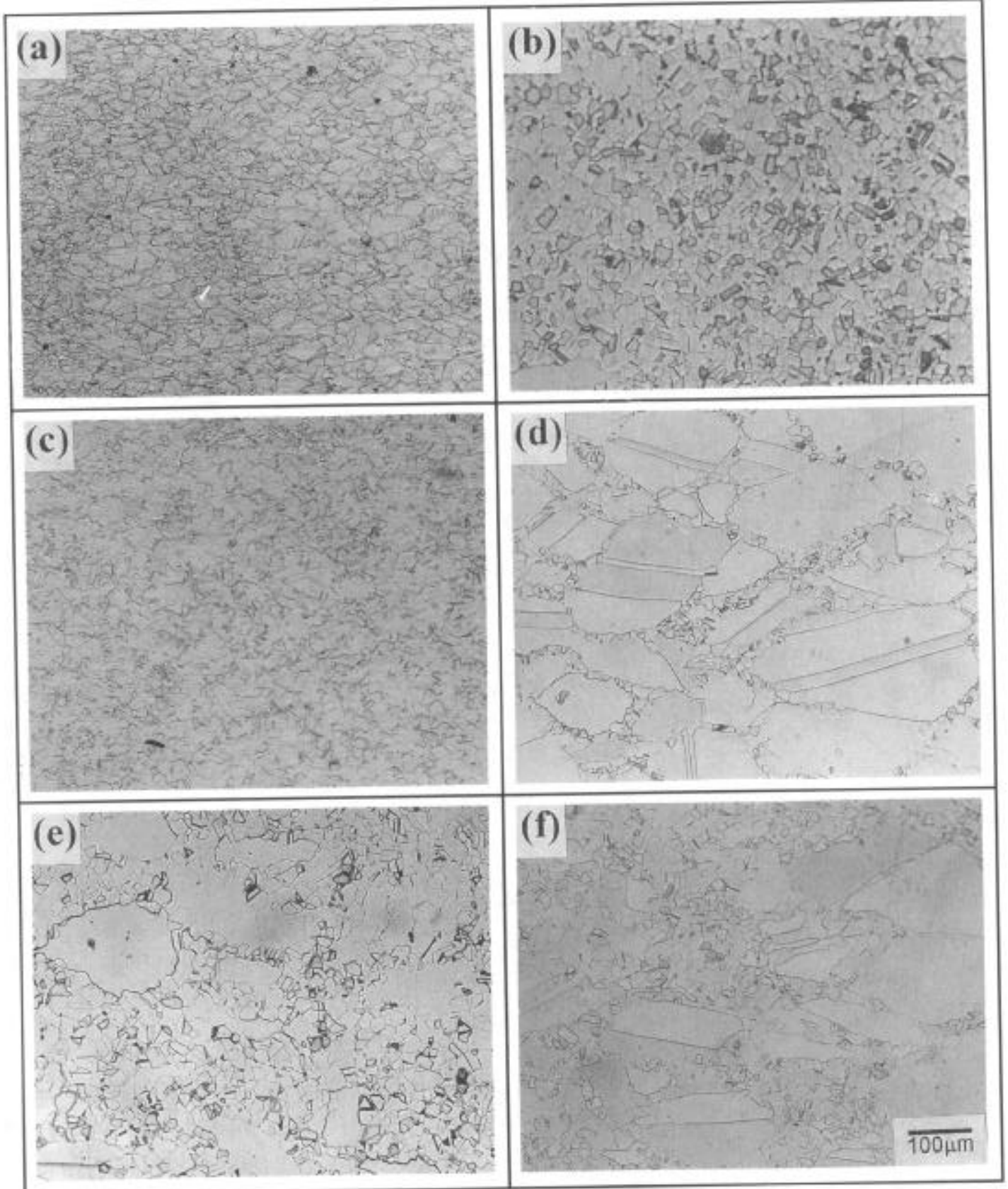

Fig. 4. Optical microstructures of forged Alloy 718 pancakes (Location 2).

(a) A , (b) B, (c) C, (d) D, (e) $\mathrm{E}$ and (f) F 


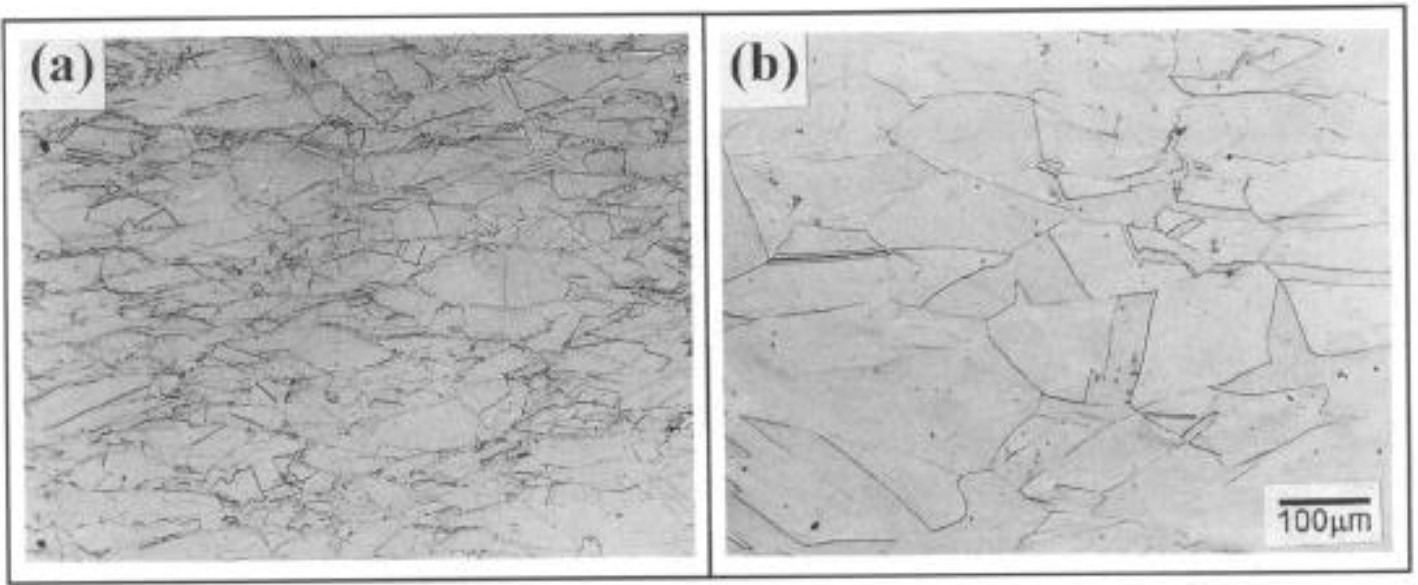

Fig. 5. Optical microstructures of forged Alloy 718 pancakes (Location 1).

(a) $\mathrm{A}$ and (b) $\mathrm{F}$

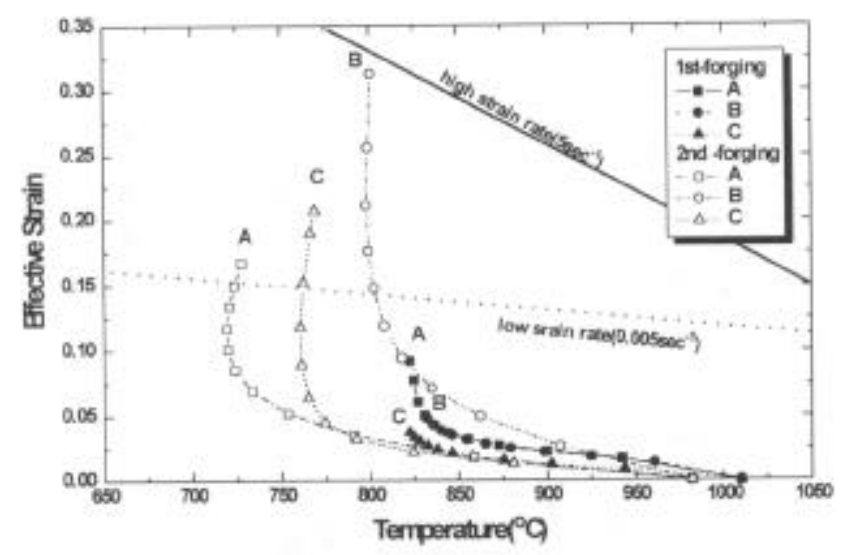

(a)

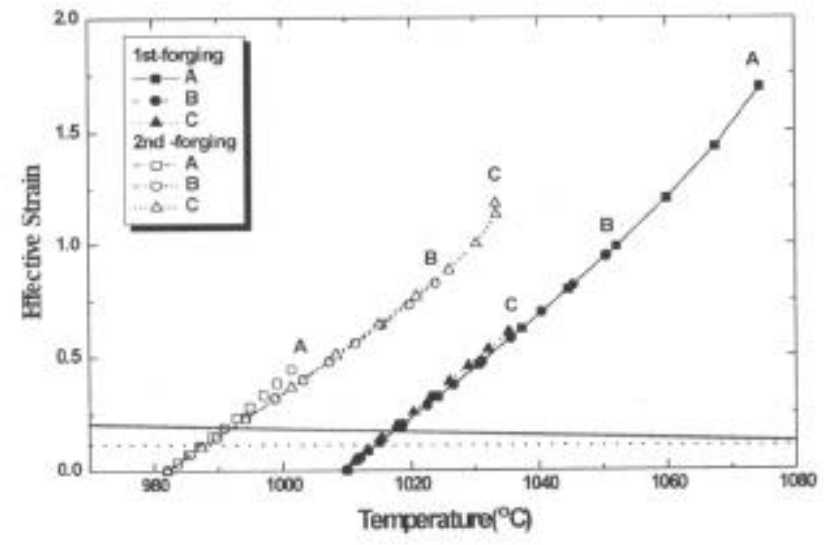

(b)

Fig.6. Variation of effective strain and temperature in A, B and C at different locations;

(a) Location 1 and (b) Location 2 
The Location 1 after the first and second forging under $\mathrm{A}, \mathrm{B}$ and $\mathrm{C}$ conditions is within the region where the recrystallization does not occur. D, E and $\mathrm{F}$ samples show a similar behavior and large-butelongated grains $(\sim 200 \mathrm{~cm})$ without any sign of recrystallization (see Figure 5(b)). The larger grains than the initial grain size of $\sim 110 \mu \mathrm{m}$ were obtained by the deformation above the $\delta$ solvus temperature $\left(\sim 1038^{\circ} \mathrm{C}\right)$. The surface deformation was affected by dynamic recovery rather than dynamic recrystallization due to lower temperatures and strains.

The Location 2 under all $\mathrm{A}, \mathrm{B}$ and $\mathrm{C}$ conditions enters the recrystallization region from the early stage of deformation during the first and second step forging. It is also shown in Location 2 that a continuous rise of temperature occurs due to deformation heating, resulting in a fine grain structure. Figure 6(b) also indicates that the temperatures and strains obtained after the first forging are in the order of A, B and C. But, the temperature and strains after the second forging are in the order of C, B and $A$. The recrystallized grain size $(\sim 15 \mathrm{~cm})$ under $C$ condition was finer than the grain sizes under $B$ and $\mathrm{A}$, but the $\mathrm{A}$ condition shows the most uniform grain size distribution (see Figure 4 ). $C$ condition which has been recrystallized in the first forging is recrystallizated again due to heavy deformation during the second forging. There might be some static recrystallization which occurred during cooling, but it was not taken into account in this study.

The microstructures of $\mathrm{D}, \mathrm{E}$ and $\mathrm{F}$ specimens are composed of necklace structures due to partial recrystallization. It is well known that the temperature rise above the $\delta$ solvus temperature leads to a rapid grain growth. The simulation of the effective strain and temperature does not depend very much on test conditions. However, the D, E and F specimens are composed of coarse grains because of a rapid grain growth in the first forging near the $\delta$ solvus temperature. The dynamic recrystallization is hindered with increasing grain size, as the number of nucleation site for new grains becomes scarce. The rate of dynamic recrystallization indeed decreases with increasing initial grain size[6,7]. In summary, a limited recrystallization has occurred around primary grain boundaries during first step forging, and the coarse grained microstructures turn into necklace microstructure during second step forging.

Table. IV. Grain size ( ASTM \#) of Location 2 under various forging conditions

\begin{tabular}{|c|c|c|}
\hline Specimens & $\begin{array}{c}\text { Recrystallized grains } \\
\mu \mathrm{m} \text { (ASTM\#) }\end{array}$ & $\begin{array}{c}\text { Unrecrystallized grains } \\
\mu \mathrm{m} \text { (ASTM\#) }\end{array}$ \\
\hline $\mathrm{A}$ & $25(7 \sim 8)$ & - \\
\hline $\mathrm{B}$ & $31(7)$ & - \\
\hline $\mathrm{C}$ & $15(8.5 \sim 9)$ & - \\
\hline $\mathrm{D}$ & $22(8)$ & $160(2-3)$ \\
\hline $\mathrm{E}$ & $32(7)$ & $90(4)$ \\
\hline $\mathrm{F}$ & $23(8)$ & $110(3 \sim 4)$ \\
\hline
\end{tabular}

Table IV shows grain sizes observed at Location 2, near the center part of the work pieces under various forging conditions. The $\mathrm{A}, \mathrm{B}$ and $\mathrm{C}$ specimens consist of a fine grain structure due to the full recrystallization and ' $\mathrm{C}$ ' specimen shows the most refined microstructure $(\sim 15 \mu \mathrm{m})$. The $\mathrm{D}, \mathrm{E}$ and $\mathrm{F}$ specimens show large grain sizes with partially recrystallized grains and $\mathrm{E}$ specimen shows the smallest grains $(\sim 90 \mathrm{\mu m})$. In summary, the grains became refined due to active dynamic 
recrystallization when the forging was done below the $\delta$ solvus temperature. Once the data base on the grain refinement is established under the compression tests, FE simulation can be utilized to predict the microstructure via prediction of local effective strain, temperature and strain rate.

The distribution of microstructures of the forged A, B and C parts is shown in Figure 7, where a comparison is made between FE simulation and actual microstructures. The center part of the work piece, which has reached a strain greater than 0.5 with a temperature rise as a result of deformation heating, consists of fully recrystallized grains, and the surface region facing upper and lower dies is composed of unrecrystallized coarse grains. Between the two regions, the microstructure is composed of partially recrystallized grains with the necklace microstructure.

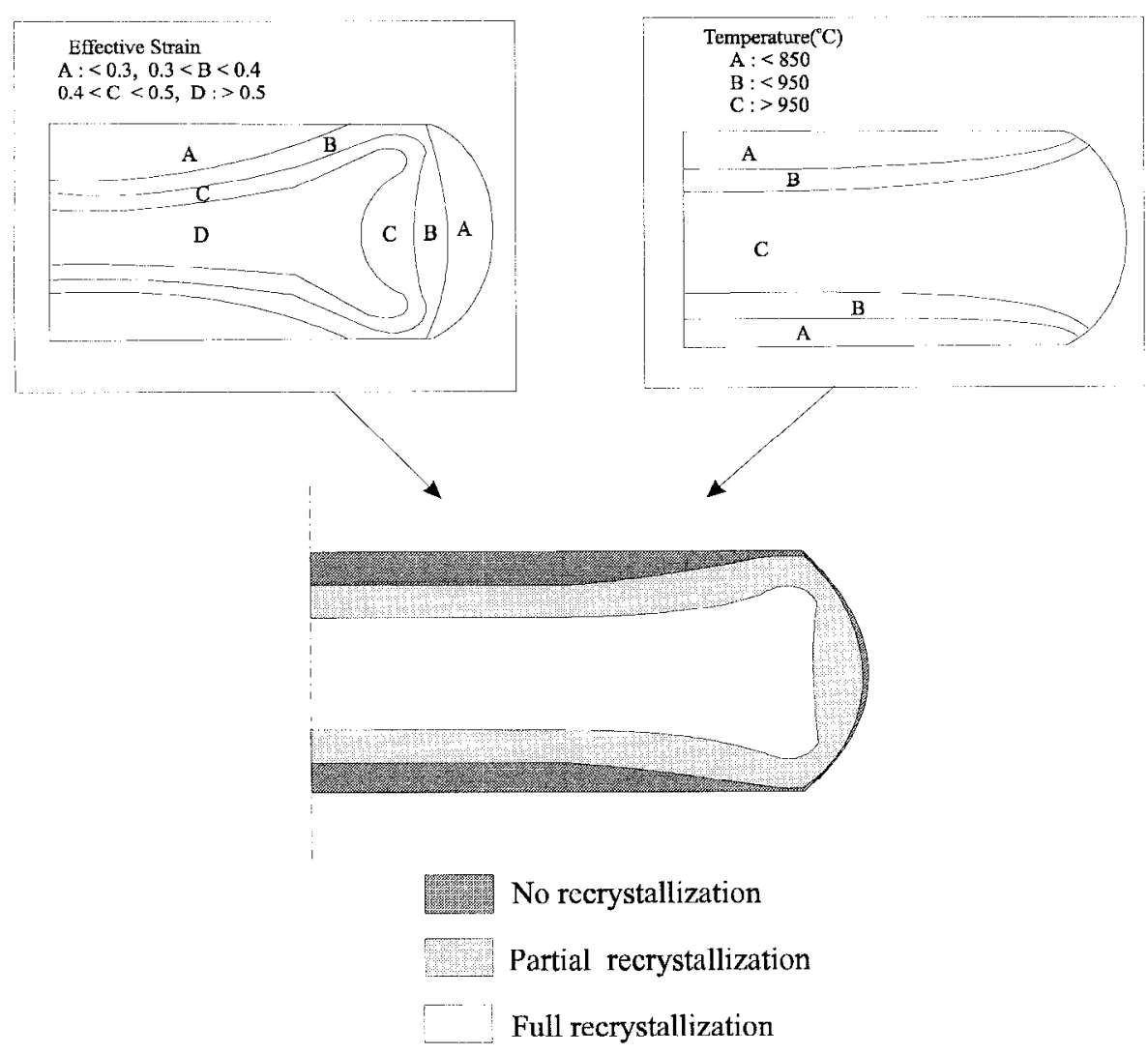

Fig. 7. Comparison of as-forging structure with predicted temperature and strain distributions.

\section{Conclusions}

1. The critical strain $\left(\varepsilon_{C}\right)$ corresponding to dynamic recrystallization was obtained from the graph of strain hardening $\operatorname{rate}(\theta)$ vs. flow stress. It was shown that the critical strain for the dynamic recrystallization increases with an increasing strain rate or decreasing forging temperature under the given test conditions. 
2. The strain and temperature distribution simulated by FEM can be effectively used to predict the evolution of microstructures of the work piece.

3. The forging above the $\delta$ solvus temperature results in the partial recrystallization because of coarse grains, but the forging below the $\delta$ solvus temperature results in the fully recrystallized fine grains.

\section{References}

1. Edward A. Loria, "The Status and Prospects of Alloy 718 ." J. Metals, 40(July 1988), 36-41

2. J. P. Sah, G. J. Richardson, and C. M. Sellars, " Grain-Size Effects during Dynamic Recrystallization of Nickel" Met. Sci., Vol 8, 1974, 325-331.

3. N. A. Wilkinson, "Forging of 718 - The inportance of T. M. P.," Superalloy 718-Metallurgy and Applications, E. A. Loria Ed., TMS, 1989, 119-133

4. W. Roberts and B. Ahlblom, "A Nucleation Criterion for Dynamic Recrystallization during Hot Working," Acta. Met., Vol. 26, 1978, 801-813

5. George Krauss, ed., Deformation, Processing, and Sructure (St. Louis, Missouri, ASM, 23 October ,1982), 231.

6. W. Roberts, H. Boden and B. Ahlblom, " Dynamic Recrystallization Kinetics," Met. Sci., Vol 13 1979, 195- 205.

7. M. J. Luton and C. M. Sellars, " Dynamic recrystallization in Nickel and Nickel-Iron Alloys During High-Temperature Deformation," Acta Met., Vol 17, 1969, 1033. 